\title{
Nano Zinc-Oxide Enhanced Photosynthetic Apparatus and Photosystem Efficiency of Maize (Zea Mays L.) in Sandy-Acidic Soils
}

\author{
Jaya Nepal \\ University of Florida \\ Xiaoping Xin \\ University of Florida \\ Zhenli He \\ University of Florida
}

Wiqar Ahmad ( $\nabla$ wiqar280@yahoo.co.uk)

University of Florida https://orcid.org/0000-0003-1787-3492

\section{Research Article}

Keywords: Chlorophyll, Carotenoids, Fluorescence, Nano fertilizer, Nano ZnO, Photosynthesis

Posted Date: January 14th, 2022

DOI: https://doi.org/10.21203/rs.3.rs-1236243/v1

License: @ (i) This work is licensed under a Creative Commons Attribution 4.0 International License. Read Full License 
1 Nano Zinc-Oxide enhanced photosynthetic apparatus and photosystem efficiency of maize 2 (Zea mays $\mathbf{L}$.) in sandy-acidic soils

3 Wiqar Ahmad ${ }^{\mathrm{a}, \mathrm{b}}$, Jaya Nepal ${ }^{\mathrm{a}}$, Xiaoping Xin ${ }^{\mathrm{a}}$, Zhenli He ${ }^{\mathrm{a} *}$,

$4 \quad{ }^{a}$ Soil and Water Science Department/Indian River Research and Education Center, Institute of Food and

5 Agricultural Sciences, University of Florida, 2199 South Rock Road, Fort Pierce, FL. 34945, USA

$6 \quad{ }^{b}$ Department of Soil and Environmental Sciences, the University of Agriculture, Peshawar, AMK Campus,

7 23200, Mardan, Pakistan.

8 Authors emails:

9 Wiqar Ahmad*: wiqar280@yahoo.co.uk / wiqar.ahmad@ufl.edu

10 Jaya Nepal: j.nepal@ufl.edu

11 Xiaoping Xin: xinxp1024@ufl.edu

12 Zhenli He: zhe@ufl.edu

13 *Corresponding Author: zhe@ufl.edu,wiqar.ahmad@ufl.edu

14 Postal address: 2199, S ROCK RD. Fort Pierce, FL 34945

15 Running Title: nano $\mathrm{ZnO}$ impact on chlorophyll and photosystems efficiency.

17

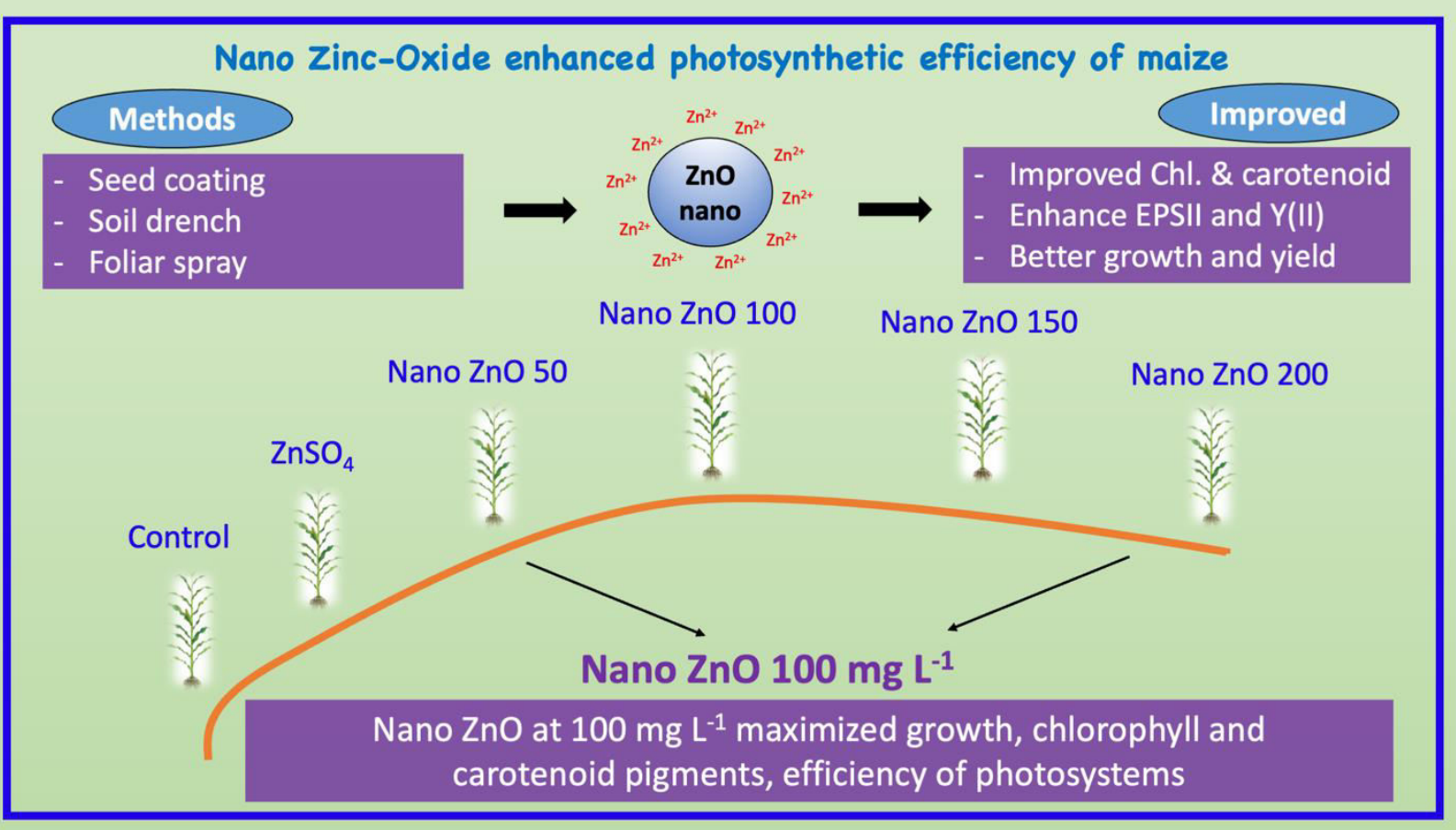




\section{Abstract}

Conventional Zinc (Zn) fertilization (e.g., zinc sulfate) often leads to poor availability in soils. Zinc oxide nanoparticles (nano $\mathrm{ZnO}$ ) can be a potential solution, but their effect on crop photosynthetic activity isn't well documented. The effects of nano $\mathrm{ZnO}\left(50,100,150,200 \mathrm{mg} \mathrm{L}^{-}\right.$ $\mathrm{ZnSO}_{4}$ recommended dose were evaluated for plant height, biomass, chlorophyll pigments and photosystem efficiency in a greenhouse pot experiment. $100 \mathrm{mg} \mathrm{L}^{-1}$ of nano $\mathrm{ZnO}$ significantly increased the chlorophyll $(C h l.) \mathrm{a}, \mathrm{b}, \mathrm{a}+\mathrm{b}$, carotenoids $(\mathrm{x}+\mathrm{c}), \mathrm{a}+\mathrm{b} / \mathrm{x}+\mathrm{c}, \mathrm{SPAD}$, leaf $C h l$. , total

31 chlorophyll content plant ${ }^{-1}$, plant height and total biological yield (by 18-30\%, 33-67\%, 22-38\%, $14-21 \%, 14-27 \%, 12-19 \%, 12-23 \% 58-99 \%, 6-11 \%$ and 16-20\%, respectively) and reduced Chl.

$33 \mathrm{a} / \mathrm{b}$ (by $6-22 \%)$ over the other treatments $(\mathrm{p}<0.01)$ irrespective of application methods. Nano

$34 \mathrm{ZnO}$ applied at $100 \mathrm{mg} \mathrm{L}^{-1}$ significantly increased photochemical quenching (qP) and efficiency 35 of photosystem II (EPSII) compared to 150 and $200 \mathrm{mg} \mathrm{L}^{-1}$ regardless of application methods. 36 The positive correlations between $C h l$. a and $C h l . \mathrm{b}\left(\mathrm{r}^{2} 0.90\right), C h l$. $\mathrm{a}+\mathrm{b}$ and $\mathrm{x}+\mathrm{c}\left(\mathrm{r}^{2}=0.71\right)$, SPAD 37 and $C h l$. a $\left(\mathrm{r}^{2}=0.90\right)$, SPAD and $C h l . \mathrm{b}\left(\mathrm{r}^{2}=0.94\right)$ and SPAD and $C h l . \mathrm{a}+\mathrm{b}\left(\mathrm{r}^{2}=0.93\right)$ indicates a uniform enhancement in chlorophyll pigments; SPAD value, $\mathrm{qP}$, EPSII, and growth and yield parameters. This elucidates that the application of nano $\mathrm{ZnO}$ at $100 \mathrm{mg} \mathrm{L}^{-1}$ promotes corn 40 biochemical health and photosynthesis, irrespective of the application method. These findings 41 have a great propounding for improving plant growth through nano $\mathrm{ZnO}$ bio-fortification in 42 acidic Spodosols. 
43 Keywords: Chlorophyll, Carotenoids, Fluorescence, Nano fertilizer, Nano ZnO, Photosynthesis

\section{Introduction:}

Zinc $(\mathrm{Zn})$ is an essential micro-nutrient required for enhancing the productivity and

47 quality of cereal crops. It is required for several plant physiological functions including enzyme

48 activation, synthesis of chlorophyll pigments and functioning of photosynthesis, and membrane

49 integrity (Nadeem \& Farooq, 2019). Therefore, Zn deficiency can potentially impact crop

50 photosynthetic apparatus and efficiency, thereby reducing the quantity and quality of the

51 products. For example, its deficiency has caused severe declines in major cereal crop

52 productivity (Hossain et al., 2019; Bhatt et al., 2020), and threatened the cereal-based cropping

53 systems (Cakmak \& Kutman, 2018; Nadeem \& Farooq, 2019). The problem is exacerbated in

54 highly alkaline (Recena et al., 2021) or acidic (García-Gómez et al., 2020) soils, where $\mathrm{Zn}^{2+}$ is

55 highly fixed, making it unavailable for crop plant uptake. Corn is a major cereal crop and

56 requires the application of $\mathrm{Zn}$ for maintaining production. The straw quality and grain $\mathrm{Zn}$ bio-

57 fortification rely on supplementation of $\mathrm{Zn}$ through chemical fertilization. However, $\mathrm{Zn}$

58 application through conventional methods (e.g., zinc sulfate) often leads to poor availability and

59 low crop uptake due to fixation reactions in soils (Elemike et al., 2019). The Zn uptake

60 efficiency is particularly low when the soil contains low organic matter, low clay content, high

61 carbonate, or low pH (Recena et al., 2021).

Nanoparticles, owing to their minute size and large reactive surface area, offer a potential

63 solution to improve nutrient uptake efficiency in agriculture (Rizwan et al., 2017). As they are

64 readily up-taken by plants, they possess a significant potential to improve crop growth and yield 
65 (Sabir et al., 2014). Zinc oxide nanoparticles (nano $\mathrm{ZnO}$ ) can be a viable alternative to enhance 66 Zn uptake in low organic matter, sandy, and highly acidic soils. Although using $\mathrm{ZnO}$ 67 nanoparticles for mitigating $\mathrm{Zn}$ deficiency and augmenting $\mathrm{Zn}$ bio-fortification of different crops 68 has previously been reported (Rizwan et al., 2017; Moghaddasi et al., 2017); their effect on crop 69 photosynthetic activity isn't well documented. Also, uptake efficiency of nano $\mathrm{ZnO}$ through 70 various methods and its possible implications on plant physiological mechanism is not 71 understood well. The availability of $\mathrm{Zn}$ also directly affects the efficiency of photosynthesis 72 systems II (PSII) as $\mathrm{Zn}$ is vital in the formation and activation of photosynthetic pigments and 73 providing energy through electron transport during light and dark reactions photosynthesis. Corn

74 biomass, stomatal conductance, and quantum yield of PSII were significantly improved through 75 Zn application under well-watered conditions (Wang et al., 2009). Zn deficiency leads to reduced 76 photosynthesis rate (Subba et al., 2014), disruption in chlorophyll membrane, leaf chlorophyll 77 content and reduction in photochemical efficiency of PSII (Chen et al., 2008). The leaf 78 chlorophyll content, chlorophyll a/b ratio, $F_{v} / F_{m}, F_{v} / F_{o}$ were significantly reduced by zinc 79 deficiency, which indicated the integral efficiency of the PSII was damaged when sufficient $\mathrm{Zn}$ 80 was not available (Chen et al., 2008). Nano zinc oxide particles have shown to improve corn 81 growth either at par or better than conventional $\mathrm{ZnSO}_{4}$ (Adhikari et al., 2015; Taheri et al., 82 2015). However, their effects on plant photosynthetic pigments and efficiency were inconsistent 83 with different crops and fluctuated based on the concentration used (Reddy Pullagurala et al., 84 2018; Salam et al., 2022). It is, thus, critical to document the effect of nano $\mathrm{ZnO}$ application not 85 only in evaluating $\mathrm{Zn}$ uptake by crops but also in understanding its implications in crop 86 photosynthetic apparatus and efficiency to identify its optimal level of application. 
In this study, the performance of nano $\mathrm{ZnO}$ was evaluated for corn plant photosynthetic

efficiency using different application modes and rates in sandy-acidic Spodosols. The major objectives were to evaluate the effect of different application rates of nano $\mathrm{ZnO}$ on crop growth as evidenced through plant growth, the robustness of photosynthetic apparatus (chlorophyll pigments, carotenoids and antioxidant activity) and photosynthetic efficiency (efficiency of photosystem II), as compared to conventional $\mathrm{Zn}$ sulfate application. Besides, Nano $\mathrm{ZnO}$ was tested through different application methods (seed coating, soil drench and foliar spray) to understand its effectiveness for photosynthetic performance, growth and $\mathrm{Zn}$ nutrition of corn.

\section{Material and methods:}

\subsection{Experimental site and soil sampling:}

The pot experiment was conducted at the greenhouse facility of the Indian River Research and Education center (IRREC), University of Florida. The soil representing the order of Spodosol (Ankona series) was sampled from the experimental farm at the research center (properties shown in Table 1). The collected soils were composited and homogenized before transporting them to the laboratory, where it was air-dried and sieved through a 1- $\mathrm{mm}$ sieve. The pre-sowing analysis of Spodosol soil to be used for this experiment is shown in Table 1.

\section{Table 1 Pre-sowing analysis of soil used for the experiment}

\begin{tabular}{llc}
\hline Parameters & Unit & Values \\
\hline $\mathrm{pH}\left(1: 2.5 \mathrm{H}_{2} \mathrm{O}\right)$ & - & 4.81 \\
$\mathrm{EC}\left(1: 5 \mathrm{H}_{2} \mathrm{O}\right)$ & $\mu \mathrm{S} / \mathrm{cm}$ & 202.15 \\
Total C & $\%$ & 0.754 \\
Total N & $"$ & 0.022 \\
Available nutrients* & $\mathrm{mg} \mathrm{kg}^{-1}$ & \\
$\mathrm{P}$ & & 28.94 \\
$\mathrm{~K}$ & $\prime$ & 30.3 \\
$\mathrm{Ca}$ & $"$ & 211.84 \\
\hline
\end{tabular}




\begin{tabular}{llc}
\hline $\mathrm{S}$ & $"$ & 47.22 \\
$\mathrm{Mg}$ & $"$ & 39.90 \\
$\mathrm{Cu}$ & $"$ & 11.69 \\
$\mathrm{~B}$ & $"$ & 1.33 \\
$\mathrm{Mo}$ & $"$ & 0.09 \\
$\mathrm{Zn}$ & $"$ & 14.54 \\
$\mathrm{Al}$ & $"$ & 48.31 \\
$\mathrm{Mn}$ & $"$ & 11.97 \\
\hline
\end{tabular}

117 pot were sown (later thinned to two plants per pot) at a depth of about $5 \mathrm{~cm}$ on April $13^{\text {th }}, 2021$ 118 and continued till 75 days after sowing (DAS). Zinc oxide nanomaterial (Alfa Aesar ${ }^{\mathrm{TM}} \mathrm{ZnO}$ nanopowder, 99\% metal basis; MW: 81.37) and Zinc sulfate $\left(\mathrm{ZnSO}_{4} .7 \mathrm{H}_{2} \mathrm{O}, \mathrm{MW}: 287.54\right)$ were 120 121 regular intervals.

*Estimated by Mehlich 3 extraction.

\subsection{Experimental design:}

The pot experiment was a completely randomized design with the following treatments: Control, recommended $\mathrm{Zn}\left(11 \mathrm{~kg} \mathrm{ha}^{-1}\right)$ applied through $\mathrm{ZnSO}_{4}$ fertilizer, nano $\mathrm{ZnO}$ - coating (50, 100, 150, $\left.200 \mathrm{mg} \mathrm{L}^{-1}\right)$, nano $\mathrm{ZnO}$ - Soil drench (50, 100, 150, $\left.200 \mathrm{mg} \mathrm{L}^{-1}\right)$ and nano $\mathrm{ZnO}$ - foliar $\left(50,100,150,200 \mathrm{mg} \mathrm{L}^{-1}\right)$. Zinc Sulfate $\left(\mathrm{ZnSO}_{4}\right)$ was applied at the rate of $11 \mathrm{~kg} \mathrm{Zn} \mathrm{ha}{ }^{-1}(5.5 \mathrm{mg}$ $\mathrm{Zn} \mathrm{kg}^{-1}$ soil) for soil application as per local recommendations (Arafat et al., 2016), hereafter referred to as $\mathrm{ZnSO} 4$ applied at the recommended dose. The In total, 14 treatments, including control, were replicated three times, making 42 pots. The pots were rotated randomly biweekly in the greenhouse. Pots were filled with $6 \mathrm{~kg}$ of soil each, and basal fertilization of potassium (K) and phosphorus (P) was applied. Nitrogen (N) was applied at the recommended dose in two split doses, 10 and 30 days after germination. All the fertilization was performed as per existing recommendations (Ahmad, 2004). Five corn seeds (Zea mays, variety Dekalb; DKC62-08) per obtained from Thermo Fisher Scientific. Irrigation was applied as per plant requirements at 


\subsection{Soil analysis:}

The soil samples were analyzed prior to the beginning of the experiment (Table 1). Soil $\mathrm{pH}\left(1: 2.5 \mathrm{H}_{2} \mathrm{O}\right)$ and electrical conductivity (EC) were measured using the $\mathrm{pH} / \mathrm{mV} /$ conductivity meter (AB 200, Fischer Scientific, PA, USA). Soil carbon and nitrogen were analyzed through dry combustion of $50 \mathrm{mg}$ sample at $1200{ }^{\circ} \mathrm{C}$ using a dry combustion $\mathrm{C} / \mathrm{N}$ analyzer (Vario MAX CN Macro Elemental Analyzer, Hanau, Germany). Available macronutrients $\mathrm{P}, \mathrm{K}, \mathrm{Ca}, \mathrm{Mg}, \mathrm{S}$ and micronutrients $(\mathrm{Fe}, \mathrm{Zn}, \mathrm{Cu}, \mathrm{Mn}, \mathrm{Al}, \mathrm{Mo}, \mathrm{B})$ in soil were extracted through Mehlich 3 extraction method (Mehlich, 1984) and their concentrations were analyzed using an Inductively coupled plasma optical emission spectrometry (ICP-OES, Ultima, J.Y. Horiba Group, Edison, N.J.).

\subsection{Growth data and plant analysis:}

Data were recorded for plant height, SPAD and fluorescence at 60 DAS. Leaf chlorophyll content was measured from two recently matured leaves per plant using a handheld SPAD chlorophyll meter (Minolta Camera, Osaka, Japan). The fluorescence parameters were recorded under actively photosynthesizing (daytime), and dark-adapted conditions using the pulse modulated chlorophyll fluorometer (OS5p+, Opti-Sciences Inc., Hudson, NH). The key parameters recorded were fluorescence under steady-state conditions i.e., before saturation $\left(\mathrm{F}_{\mathrm{s}}\right)$, maximum fluorescence with actinic illumination at steady-state fluorescence $\left(\mathrm{F}_{\mathrm{ms}}\right)$, quantum photosynthetic yield of photosystem II (Y), minimum fluorescence $\left(\mathrm{F}_{\mathrm{o}}\right)$, maximal fluorescence (Fm) and maximum photochemical efficiency of PSII $\left(\mathrm{F}_{\mathrm{v}} / \mathrm{F}_{\mathrm{m}}\right)$ [nighttime]. The following calculations were performed to calculate photochemical quenching (qP) and non-photochemical quenching (qN) based on Oxborough \& Baker (1997) 


$$
\begin{aligned}
& q P=\frac{F_{m s}-F}{F_{m s}-F o^{\prime}} \\
& q N=\frac{F_{m}-F_{m s}}{F_{m s}}
\end{aligned}
$$

144 Where Fo' is adjusted minimum fluorescence calculated as,

$$
F o^{\prime}=\frac{F_{0}}{\left(1-\frac{F o}{F m}-\frac{F o}{F m s}\right)}
$$

Chlorophyll and carotenoids were estimated by the methods suggested by Lichtenthaler

147 during the growth of the crop (60DAS) from each pot, crushed and mixed with $10 \mathrm{~mL}$ of $80 \%$

148 acetone. The mixture was protected from the light by covering with parafilm and preserving in 149 the refrigerator in dark conditions overnight (24h) to allow for complete digestion of chlorophyll 150 pigments. The filtrates were then analyzed using the UV-Spectrophotometer (U-3110, Hitachi, 151 Japan) at the wavelength of 663,645 , and 470nm to determine chlorophyll (Chl.) a, Chl. b, and 152 carotenoid $(x+c)$ contents using the following equations.

$$
\begin{aligned}
& \text { Chl a }(m g g-1)=\frac{(12.21 * A 663)-(2.81 * A 645) * \text { Volume }(m l)}{\text { weight of the sample }(F W)(g) * 1000} \\
& \text { Chl b }(\operatorname{mgg}-1)=\frac{(20.13 * A 645)-(5.03 * A 663) * \text { Volume }(\mathrm{ml})}{\text { weight of the sample }(F W)(g) * 1000} \\
& x+c(\operatorname{mgg}-1)=\left\{\frac{((1000 * \text { A470 }) * \text { volume }(\mathrm{ml}))}{\text { sample weight }(F W)(g) * 1000}-(3.27 * \text { Chl a })-(104 * \text { Chl b) }\} / 229\right.
\end{aligned}
$$

153 Where FW = Fresh weight, A $(663,645,470)=$ Absorbance at 663, 645 and $470 \mathrm{~nm}$ 
157 glacial acetic acid followed by incubation in a water bath $\left(90^{\circ} \mathrm{C}\right)$ for 1 hour. After cooling, the 158 samples were added with $4 \mathrm{~mL}$ of Toluene, followed by shaking (20mins) and incubation at room 159 temperature to develop the toluene-proline layer. $1 \mathrm{~mL}$ liquid from the upper toluene-proline 160 layer was sucked and analyzed at 520nm using the UV-Spectrophotometer. Proline concentration 161 was calculated in $\mu \mathrm{mol} \mathrm{g}^{-1}$ fresh weight using the given equation.

$$
\text { Proline }(\mu \mathrm{mol} / \mathrm{g})=\frac{(A 520 * 20) * \text { Volume }(\mathrm{ml})}{\text { weight of the sample }(F W)(g) * 1.47 * M W}
$$

162 Where; A520= Absorbance at $520 \mathrm{~nm}, \mathrm{MW}=$ molecular weight of proline

\subsection{Statistical analysis:}

All data were statistically analyzed with Statistix 8.1 software. The data were plotted as

166

167

168

169

170

171

172

173

174

175

176

177 the mean values for each treatment along with the standard errors. All the statistical analysis was performed at the significance level of 0.05 . The treatment effects on different parameters were assessed through analysis of variance (ANOVA) after testing for the homogeneity of variance, followed by a post-hoc test [Least Significant Difference (LSD) test] was conducted to identify significantly different treatments.

\section{Results}

\subsection{Chl. a, Chl. b, Chl. $a+b$ and Chl. a/b ratio}

Zinc treatments significantly $(\mathrm{p}<0.01)$ improved maize chlorophyll a $(C h l$. a), Chl. b, total $C h l .(\mathrm{a}+\mathrm{b})$ concentration, weight ratio of $C h l$. a and $C h l . \mathrm{b},(\mathrm{a} / \mathrm{b})$ over control treatment (Table 2). The increment at $100 \mathrm{mg} \mathrm{L}^{-1}$ nano $\mathrm{ZnO}$ was maximum and higher by $29 \%$ and $31 \%$ for Chl. a and $51 \%$ and $67 \%$ for Chl. b over the recommended $\mathrm{ZnSO}_{4}$ dose and the control, respectively. Also, the nano $\mathrm{ZnO} 100 \mathrm{mg} \mathrm{L}^{-1}$ treatment had the maximum Chl. $\mathrm{a}+\mathrm{b}$ and a 
178 minimum weight ratio of $C h l$. a/b indicating a significant $(\mathrm{p}<0.01)$ difference of $38 \%$ for $C h l$.

$179 \mathrm{a}+\mathrm{b}$ and $20 \%$ for $C h l$. $\mathrm{a} / \mathrm{b}$ ratio with the control. The $\mathrm{a} / \mathrm{b}$ ratio was significantly $(\mathrm{p}<0.01)$ lower 180 for nano $\mathrm{ZnO} 100 \mathrm{mg} \mathrm{L}^{-1}$ application, and the higher value of a/b ratio of nano $\mathrm{ZnO} 200 \mathrm{mg} \mathrm{L}^{-1}$ 181 and $\mathrm{ZnSO}_{4}$ indicate significantly poor performance $(\mathrm{p}<0.01)$ among zinc treatments. $C h l$. $\mathrm{a}+\mathrm{b}$ for $18250 \mathrm{mg} \mathrm{L}^{-1}$ nano $\mathrm{ZnO}$ was significantly $(\mathrm{p}<0.01)$ lower (by $22 \%$ and $18 \%$, respectively) than nano $183 \mathrm{ZnO} 100 \mathrm{mg} \mathrm{L}^{-1}$ and $150 \mathrm{mg} \mathrm{L}^{-1}$ but statistically similar with nano $\mathrm{ZnO} 200 \mathrm{mg} \mathrm{L}^{-1}$. However, $184 C h l$. a/b for nano $\mathrm{ZnO} 50 \mathrm{mg} \mathrm{L}^{-1}$ and $150 \mathrm{mg} \mathrm{L}^{-1}$ were statistically similar to other Zn treatments 185 including $100 \mathrm{mg} \mathrm{L}^{-1} \mathrm{ZnO} \mathrm{NP}$, but significantly ( $\left.\mathrm{p}<0.01\right)$ lower (by $11 \%$ and $13 \%$, respectively) 186 than the control (Table 2). Results (Table 2) further showed that the impact of application 187 methods on $C h l$. a, Chl. b, Chl. a+b and $C h l$. a/b values were non-significant. However, with the 188 foliar application, a $4 \%$ and $3 \%$ improvement in Chl. a, 10\% and 1\% in Chl. b was observed over 189 the soil drench and seed coating, respectively. Similarly, a 3\% and 5\% higher Chl. a+b value 190 with foliar application of nano $\mathrm{ZnO}$ over the seed coating and soil drench; and a 4\% higher Chl. $191 \mathrm{a} / \mathrm{b}$ with soil drench each over the seed coating and foliar application was observed, respectively. 192 A significant correlation between Chl. a and $\mathrm{b}\left(\mathrm{r}^{2}=0.90\right), \mathrm{a}+\mathrm{b}$ and $\mathrm{x}+\mathrm{c}\left(\mathrm{r}^{2}=0.71\right)$ was observed. Interaction between the $\mathrm{Zn}$ treatments and application methods for Chl. a and Chl. $\mathrm{a}+\mathrm{b}$ 194 was non-significant but was significant for $C h l$. b and $C h l$. a/b values. It was observed from data 195 (Fig. 1a) that lower to moderate nano $\mathrm{ZnO}$ doses were effective for improving Chl. b in maize 196 with the foliar application, higher doses were effective with soil drench and a moderate dose of $197100 \mathrm{mg} \mathrm{L}^{-1} \mathrm{ZnO}$ NP was significantly higher in $C h l$. b when applied as seed coating. For $C h l$. a/b 198 (Fig. 2b), lower to moderate nano $\mathrm{ZnO}$ doses resulted in lower $C h l$. a/b ratio with foliar 199 application and seed coating at $100 \mathrm{mg} \mathrm{L}^{-1} \mathrm{ZnO} \mathrm{NP}$ treatment was the lowest. 
Table 2: Maize biochemical parameters as affected by different doses and modes of application of nano $\mathrm{ZnO}$ in comparison with recommended dose of $\mathrm{ZnSO}_{4}$ applied as soil.

\begin{tabular}{|c|c|c|c|c|c|c|c|}
\hline \multirow{2}{*}{ Zn Treatments } & Chl. a & Chl. b & $\mathbf{a} / \mathbf{b}$ & $\begin{array}{c}\text { T. Chl. } \\
(\mathbf{a}+\mathbf{b})\end{array}$ & $\begin{array}{c}\text { Carot. } \\
(\mathrm{x}+\mathrm{c})\end{array}$ & \multirow{2}{*}{$\begin{array}{c}a+b / x+c \\
-\end{array}$} & \multirow{2}{*}{$\begin{array}{c}\text { Proline } \\
\mu \mathrm{mol} \mathbf{g}^{-1} \\
(\mathrm{FW})\end{array}$} \\
\hline & \multicolumn{2}{|c|}{$\ldots \operatorname{mg~g}^{-1}(F W) \ldots$} & - & \multicolumn{2}{|c|}{.. $\mathrm{mg} \mathrm{g}^{-1}(\mathrm{FW})$.. } & & \\
\hline Cont. & $2.31 \mathrm{~b}$ & $0.55 \mathrm{c}$ & $4.19 \mathrm{a}$ & $2.87 \mathrm{c}$ & $0.51 \mathrm{bc}$ & $5.61 \mathrm{c}$ & $10.11 \mathrm{a}$ \\
\hline $\mathrm{ZnSO}_{4}(\mathrm{RD})$ & $2.35 \mathrm{~b}$ & $0.61 \mathrm{c}$ & $3.92 \mathrm{ab}$ & $2.96 \mathrm{c}$ & $0.48 \mathrm{c}$ & $6.14 \mathrm{bc}$ & $1.72 \mathrm{c}$ \\
\hline ZnO NP50 & $2.56 \mathrm{~b}$ & $0.69 \mathrm{bc}$ & $3.78 \mathrm{bc}$ & $3.24 \mathrm{bc}$ & $0.56 \mathrm{ab}$ & $5.77 \mathrm{c}$ & $9.65 \mathrm{a}$ \\
\hline ZnO NP100 & $3.02 \mathrm{a}$ & $0.92 \mathrm{a}$ & $3.5 \mathrm{c}$ & $3.95 \mathrm{a}$ & $0.58 \mathrm{a}$ & $6.84 \mathrm{a}$ & $9.09 a b$ \\
\hline ZnO NP150 & $3.00 \mathrm{a}$ & $0.82 \mathrm{ab}$ & $3.70 \mathrm{bc}$ & $3.82 \mathrm{a}$ & $0.59 \mathrm{a}$ & $6.44 \mathrm{ab}$ & $3.68 b c$ \\
\hline ZnO NP200 & $2.94 \mathrm{a}$ & $0.76 \mathrm{~b}$ & $3.94 \mathrm{ab}$ & $3.70 \mathrm{ab}$ & $0.60 \mathrm{a}$ & $6.18 \mathrm{bc}$ & $5.99 \mathrm{abc}$ \\
\hline $\operatorname{LSD}_{(p<0.05)}$ & $0.34 * *$ & $0.16^{* *}$ & $0.38 *$ & $0.48 * *$ & $0.06^{* *}$ & $0.58 * *$ & $5.66^{*}$ \\
\hline $\begin{array}{l}\text { Methods of } \\
\text { (MnA) }\end{array}$ & Application & & & & & & \\
\hline Coating & 2.68 & 0.74 & 3.80 & 3.42 & 0.56 & $6.13 \mathrm{ab}$ & 5.55 \\
\hline Soil & 2.65 & 0.68 & 3.94 & 3.34 & 0.56 & $5.92 \mathrm{~b}$ & 8.73 \\
\hline Foliar & 2.76 & 0.75 & 3.77 & 3.51 & 0.54 & $6.44 \mathrm{a}$ & 5.84 \\
\hline $\operatorname{LSD}_{(\mathbf{p}<0.05}$ & ns & ns & ns & ns & ns & $0.41 *$ & ns \\
\hline $\begin{array}{l}\text { Interaction } \\
(\mathbf{Z n} * \text { MoA })\end{array}$ & ns & $*$ (Fig. 2) & $*$ (Fig. 3) & ns & ns & $* *($ Fig. 4) & ns \\
\hline
\end{tabular}

203 FW= Fresh weight, Chl. a: Chl. a, Chl. b: Chl. b, T.Chl..: total Chl., Carot.: carotenoids, ZnO NP50 : 204 ZnO NP $50 \mathrm{mg} \mathrm{L}^{-1}$, ZnO NP100: ZnO NP $100 \mathrm{mg} \mathrm{L}^{-1}$, ZnO NP150: ZnO NP $150 \mathrm{mg} \mathrm{L}^{-1}$, ZnO NP200:

$205 \mathrm{ZnO} \mathrm{NP} 200 \mathrm{mg} \mathrm{L}^{-1}$. In a column, means followed by different letters vary significantly at the $p<0.05$. 

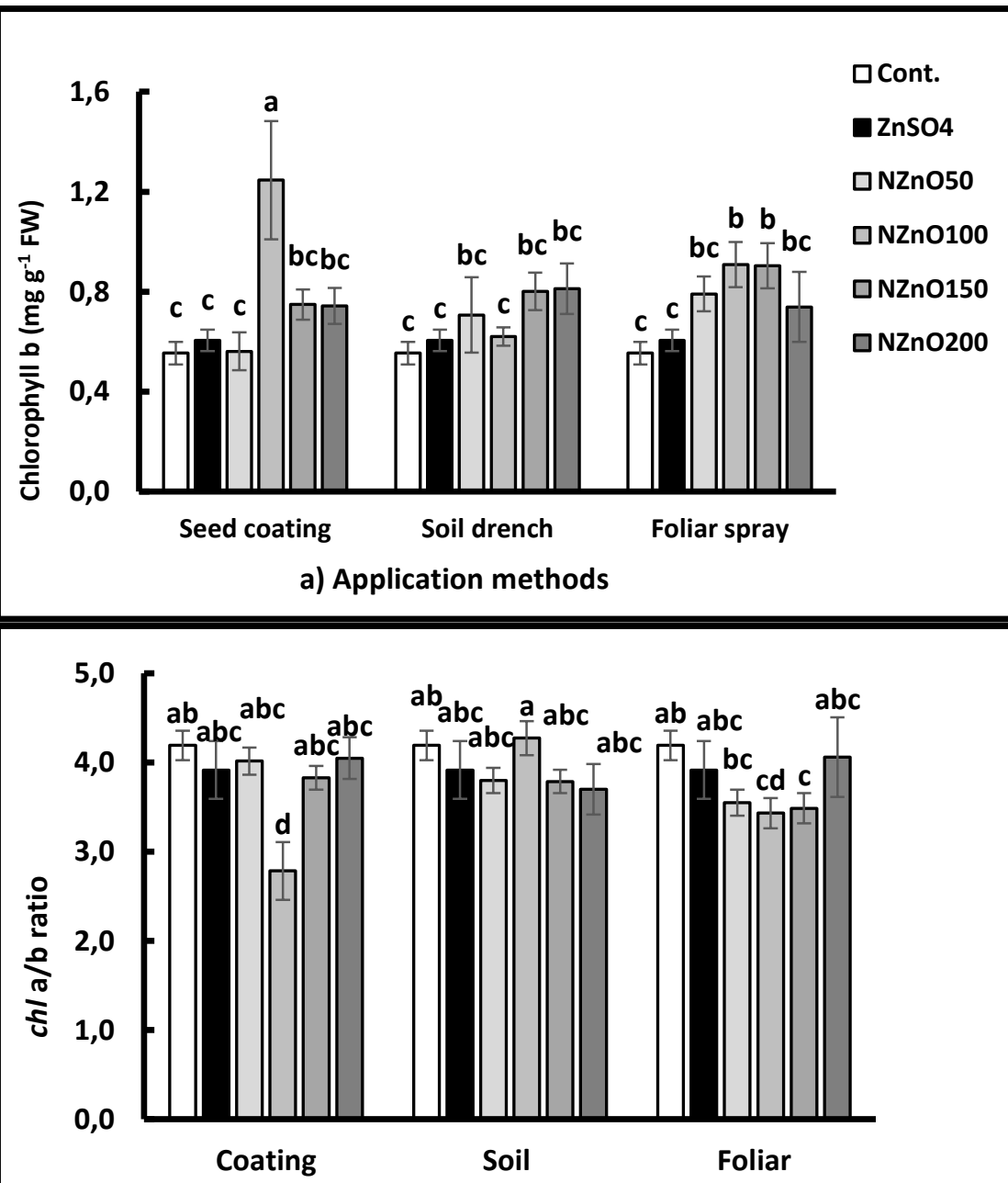

(b) Application methods

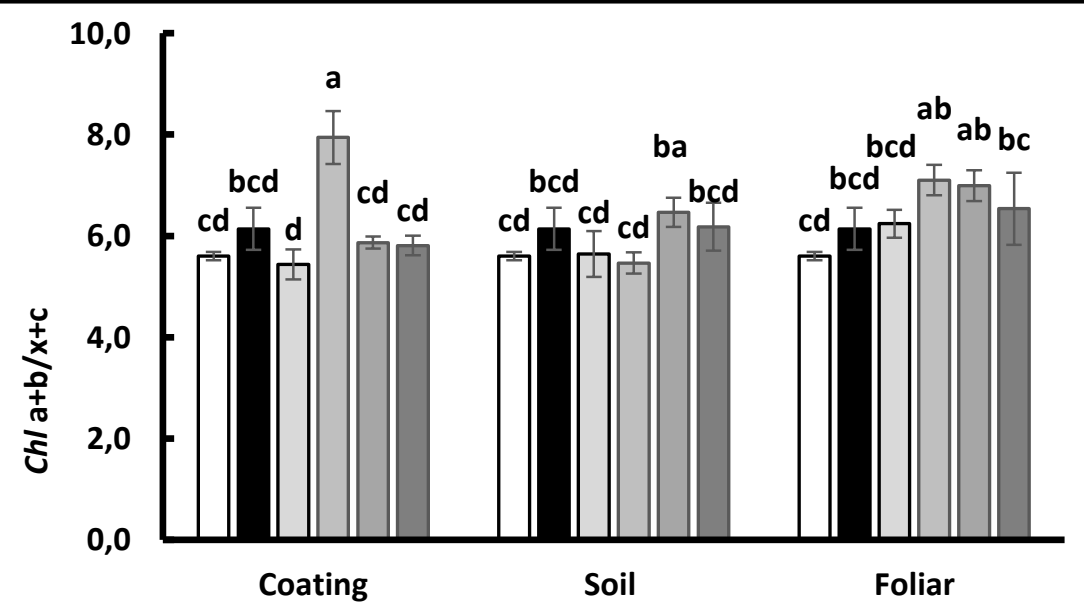

(c) Application methods

Figure 1 Interaction effect of nano ZnO treatments and their application methods on (a) Chl. $b$ concentration (b) Chl. $a / b$ ratio (c) Chl. $a+b / x+c$ ratio and of maize crop 

carotenoids $(x+c)$, the weight ratio of total $C h l$. $(\mathrm{a}+\mathrm{b})$ to carotenoids $(\boldsymbol{a}+\boldsymbol{b} / \boldsymbol{x}+\boldsymbol{c})$ and proline in maize crop. The nano $\mathrm{ZnO}$ treatments were statistically similar in $x+c$ but significantly $(\mathrm{p}<0.01)$

218 higher than the $\mathrm{ZnSO}_{4}$. However, the extent of $x+c$ increased with increasing dose of nano $\mathrm{ZnO}$ 219 and was maximum for $200 \mathrm{mg} \mathrm{L}^{-1}$ followed by 150,100 and $50 \mathrm{mg} \mathrm{L}^{-1}$ nano $\mathrm{ZnO}$ treatments. 220 The weight ratio of $C h l . a+b / x+c$ for nano $\mathrm{ZnO} 100 \mathrm{mg} \mathrm{L}^{-1}$ was maximum followed by 150 and $221200 \mathrm{mg} \mathrm{L}^{-1}$ while all the three were significantly $(\mathrm{p}<0.01)$ higher (by $27 \%, 22 \%$, and $13 \%$, 222 respectively) than the lowest $C h l . a+b / x+c$ ratio in the control. Furthermore, the 100 and 150 $223 \mathrm{mg} \mathrm{L}^{-1}$ nano $\mathrm{ZnO}$ doses were significantly $(\mathrm{p}<0.01)$ higher in $C h l . a+b / x+c$ ratio (by $22 \%$ and $22414 \%$, respectively) than the nano $\mathrm{ZnO} 50 \mathrm{mg} \mathrm{L}^{-1}$ (Table 2). The $\mathrm{Zn}$ control had the highest and $225 \mathrm{ZnSO}_{4}$ the lowest proline concentration while both differed significantly $(\mathrm{p}<0.01)$ with a 5-fold 226 difference approximately. Amongst the nano $\mathrm{ZnO}$ solution concentrations, $50 \mathrm{mg} \mathrm{L}^{-1}$ was highest 227 in proline, statistically similar to the control, significantly $(\mathrm{p}<0.01)$ higher (by 162\%) than 150 $228 \mathrm{mg} \mathrm{L}^{-1}$ and $6 \%$ and $60 \%$ higher than the nano $\mathrm{ZnO} 100 \mathrm{mg} \mathrm{L}^{-1}$ and $200 \mathrm{mg} \mathrm{L}^{-1} \mathrm{ZnO} \mathrm{NP}$ 229 treatments, however, they were statistically similar (Table 2).

Application methods were non-significant for $\mathrm{x}+\mathrm{c}$ and proline but their impact was significant on Chl. $a+b / x+c$ ratio. Soil drench had an edge ( $>>0.05)$ of $1.7 \%$ and $5 \%$ in $\mathrm{x}+\mathrm{c}$ and $23257 \%$ and $50 \%$ in proline over seed-coating and foliar application, respectively. Foliar application was significantly $(\mathrm{p}<0.05)$ higher in $C h l . a+b / x+c$ ratio (by 10\%) than soil drench but had an 234 edge of $6 \%(\mathrm{p}>0.05)$ over the seed coating of the nano $\mathrm{ZnO}$ while the latter two methods were 235 statistically similar (Table 2). The interactions between $\mathrm{Zn}$ treatments and their application methods affecting the $\mathrm{x}+\mathrm{c}$ and proline concentration were non-significant but highly significant 
237 ( $\mathrm{p}<0.01$ ) for Chl. $a+b / x+c$ ratio. Data (Fig. 1) revealed that the performance of the nano $\mathrm{ZnO}$ $238100 \mathrm{mg} \mathrm{L}^{-1}$ was significantly $(\mathrm{p}<0.01)$ higher compared to other treatments applied at either 239 method except for the nano $\mathrm{ZnO} 150 \mathrm{mg}^{-1}$ applied as foliar. In soil drench, the higher nano $240 \mathrm{ZnO}$ doses (150 and $200 \mathrm{mg} \mathrm{L}^{-1}$ ) performed superior over the nano $\mathrm{ZnO} 100$ and $50 \mathrm{mg} \mathrm{L}^{-1}$, $241 \mathrm{ZnSO}_{4}$ and the control treatments to a non-significant extent. However, with foliar application, 242 the nano $\mathrm{ZnO} 100$ and $150 \mathrm{mg} \mathrm{L}^{-1}$ were significantly higher than the $\mathrm{ZnSO}_{4}$ and the control 243 treatments. total Chl. content plant ${ }^{-1}$ over the non-Zn treatment whilst nano $\mathrm{ZnO}$ recorded a further 247 significant $(\mathrm{p}<0.01)$ increase over the $\mathrm{ZnSO}_{4}$ (Table 3). Amongst the nano $\mathrm{ZnO}$ treatments, 100 $248 \mathrm{mg} \mathrm{L}^{-1}$ was higher in SPAD and leaf Chl. by $8 \%(\mathrm{p}<0.05)$ and $12 \%(\mathrm{p}<0.05)$ than $50 \mathrm{mg} L^{-1}$, by $2493 \%(\mathrm{p}>0.05)$ and $4 \%(\mathrm{p}>0 ; .05)$ than $150 \mathrm{mg} \mathrm{L}^{-1}$ and by $4 \%(\mathrm{p}>0.05)$ and $6 \%(\mathrm{p}>0.05)$ than 200 $250 \mathrm{mg} \mathrm{L}^{-1}$, respectively. The maximum Chl. content plant ${ }^{-1}$ recorded with $100 \mathrm{mg} \mathrm{L}^{-1}$ nano $\mathrm{ZnO}$ was 251 statistically similar with $150 \mathrm{mg} \mathrm{L}^{-1}$ but significantly $(\mathrm{p}<0.01)$ higher than the $50 \mathrm{mg} \mathrm{L}^{-1}$ (by $25235 \%$ ), $200 \mathrm{mg} \mathrm{L}^{-1}$ nano $\mathrm{ZnO}$ (by 17\%), $\mathrm{ZnSO}_{4}$ (by 58\%) and the $\mathrm{Zn}$ control (by $99 \%$ ).

Table 3: Maize SPAD and fluorescence parameters as affected by different levels and modes of nano $\mathrm{ZnO}$ in comparison with $\mathrm{ZnSO}_{4}$ applied as soil

\begin{tabular}{lcllllll}
\hline Zn Treatments & SPAD & $\begin{array}{l}\text { Chl. } \\
\text { Conc. }\end{array}$ & $\begin{array}{l}\text { Total } \\
\text { Chl.. }\end{array}$ & EPSII & Y (II) & qP & qNP \\
& - & $\begin{array}{l}\text { nmol } \\
\mathbf{c m}^{-2}\end{array}$ & $\begin{array}{l}\boldsymbol{\mu} \text { Mmol } \\
\text { plant }^{-1}\end{array}$ & & & & \\
\hline Cont. & $37.9 \mathrm{~d}$ & $31.2 \mathrm{~d}$ & $37.3 \mathrm{e}$ & $0.8120 \mathrm{~b}$ & $0.694 \mathrm{~b}$ & $0.865 \mathrm{~b}$ & $0.135 \mathrm{a}$ \\
$\mathrm{ZnSO}_{4}(\mathrm{RD})$ & $40.3 \mathrm{c}$ & $34.0 \mathrm{c}$ & $47.0 \mathrm{de}$ & $0.8143 \mathrm{a}$ & $0.706 \mathrm{ab}$ & $0.903 \mathrm{a}$ & $0.097 \mathrm{~b}$ \\
$\mathrm{ZnO} \mathrm{NP50}$ & $41.8 \mathrm{bc}$ & $35.9 \mathrm{bc}$ & $54.8 \mathrm{~cd}$ & $0.8139 \mathrm{ab}$ & $0.716 \mathrm{a}$ & $0.915 \mathrm{a}$ & $0.085 \mathrm{~b}$
\end{tabular}




$\begin{array}{llllllll}\text { ZnO NP100 } & 45.2 \mathrm{a} & 40.4 \mathrm{a} & 74.0 \mathrm{a} & 0.8154 \mathrm{a} & 0.719 \mathrm{a} & 0.921 \mathrm{a} & 0.079 \mathrm{~b} \\ \text { ZnO NP150 } & 43.9 \mathrm{a} & 38.7 \mathrm{a} & 66.3 \mathrm{ab} & 0.8156 \mathrm{a} & 0.710 \mathrm{a} & 0.909 \mathrm{a} & 0.091 \mathrm{~b} \\ \text { ZnO NP200 } & 43.3 \mathrm{ab} & 38.0 \mathrm{ab} & 63.4 \mathrm{bc} & 0.8141 \mathrm{ab} & 0.711 \mathrm{a} & 0.910 \mathrm{a} & 0.090 \mathrm{~b} \\ \text { LSD }_{(\mathbf{p}<\mathbf{0 . 0 5})} & 1.98^{* *} & 2.56^{* *} & 10.6^{* *} & 0.00218^{*} & 0.0143^{*} & 0.0211^{* *} & 0.0211^{* *}\end{array}$

Methods of Application

$\begin{array}{llllllll}\text { Coating } & 42.4 & 36.9 & 59.5 & 0.8145 & 0.710 & 0.902 & 0.098 \\ \text { Soil } & 41.7 & 36.0 & 55.2 & 0.8140 & 0.711 & 0.902 & 0.098 \\ \text { Foliar } & 42.0 & 36.3 & 56.7 & 0.8142 & 0.707 & 0.908 & 0.092 \\ \text { LSD }_{(\mathbf{p}<\mathbf{0 . 0 5}} & \text { ns } & \text { ns } & \text { ns } & \text { ns } & \text { ns } & \text { ns } & \text { ns } \\ \text { Zn } * \text { MoA } & \text { ns } & \text { ns } & \text { ns } & \text { ns } & \text { ns } & \text { ns } & \text { ns }\end{array}$

Carot.: carotenoids, ZnO NP50: ZnO NP $50 \mathrm{mg} \mathrm{L}^{-1}$, ZnO NP100: ZnO NP $100 \mathrm{mg} \mathrm{L}^{-1}$, ZnO NP150: ZnO NP $150 \mathrm{mg} \mathrm{L} \mathrm{L}^{-1}$, ZnO NP200: ZnO NP $200 \mathrm{mg} \mathrm{L}^{-1}$.EPSII: efficiency of photosystem II, $Y($ II $)=q u a n t u m$ photosynthetic yield of PSII, $q P=$ photochemical quenching, $q N P=$ non-photochemical quenching. In a column, means followed by different letters vary significantly at the $p<0.05$.

Results further indicated the impact of the application methods and their interaction with $\mathrm{Zn}$ treatments on the SPAD, leaf $C h l$. and total $C h l$. plant ${ }^{-1}$ of the corn crop was non-significant (Table 3). However, seed coating of nano $\mathrm{ZnO}$ showed up to $8 \%(\mathrm{p}>0.05)$ and $5 \%(\mathrm{p}>0.05)$ improvement in total $C h l$. plant $^{-1}$ over the soil drench and foliar application methods. SPAD value had a significantly higher correlation with extractable $C h l$. a $\left(\mathrm{r}^{2}=0.90\right)$, Chl. b $\left(\mathrm{r}^{2}=0.94\right)$ and Chl. $\mathrm{a}+\mathrm{b}\left(\mathrm{r}^{2}=0.93\right)$ and support the data recorded for Chl. a, Chl. b and Chl. a+b with spectrophotometer (Fig 2).

\subsection{Efficiency of (EPSII) and quantum photosynthetic yield (Y) of photosystem II}

Zinc treatments significantly $(\mathrm{p}<0.05)$ improved the efficiency of photosystem II (EPS II) as well as the quantum photosynthetic yield of PSII (Y) over the control. As for the EPS II, the 100 $\mathrm{mg} \mathrm{L}^{-1}, 150 \mathrm{mg} \mathrm{L}^{-1}$ nano $\mathrm{ZnO}$ and the $\mathrm{ZnSO}_{4}$ were statistically similar but significantly $(\mathrm{p}<0.05)$

higher than the control, however, nano $\mathrm{ZnO} 100$ and $150 \mathrm{mg} \mathrm{L}^{-1}$ higher by $0.14 \%$ and $0.16 \%$, 
271 respectively, over the $\mathrm{ZnSO}_{4}$. It was evident from the data (Table 3) that EPS II was lowered at a 272 concentration above $150 \mathrm{mg} \mathrm{L}^{-1}$ and below $100 \mathrm{mg} \mathrm{L}^{-1}$ nano $\mathrm{ZnO}$. The $\mathrm{Y}$ (II) with all nano $\mathrm{ZnO}$

273 doses was significantly $(\mathrm{p}<0.05)$ higher than the control, however, it had a non-significant 274 improvement (1.8\%) over the $\mathrm{ZnSO}_{4}$ (Table 3). Amongst the nano $\mathrm{ZnO}$ treatments, the 275 maximum Y (II) was recorded with $100 \mathrm{mg} \mathrm{L}^{-1}$ nano $\mathrm{ZnO}$, which was significantly $(\mathrm{p}<0.01)$ 276 higher (by $3.6 \%$ ) over the control followed by 50, 200 and $150 \mathrm{mg} \mathrm{L}^{-1}$ nano $\mathrm{ZnO}$ with $3.2 \%$, $2772.4 \%$ and $2.3 \%$ increase, respectively. The effect of application methods and their interaction 278 with Zn treatments on the Y(II) and EPS II was non-significant.

\subsection{Photochemical quenching (qP) and non-photochemical quenching $(q N)$}

Results (Table 3) indicated a highly significant $(\mathrm{p}<0.01)$ increase in photochemical quenching (qP) because of $\mathrm{Zn}$ treatments and vice versa for non-photochemical quenching (qN).

282 The highest $\mathrm{qP}$ and lowest $\mathrm{qN}$ were recorded for $100 \mathrm{mg} \mathrm{L}^{-1}$ nano $\mathrm{ZnO}$ which was significantly $283(\mathrm{p}<0.01)$ higher (by 6\%) over the control and non-significantly higher over the other $\mathrm{Zn}$ 284 treatments and vice versa in $\mathrm{qN}$. Also, $\mathrm{qP}$ in the $\mathrm{ZnSO}_{4}$ treatment was higher significantly $285(\mathrm{p}<0.01$; by $4 \%)$ and $\mathrm{qN}$ lower by the same extent over the control treatment. Amongst the nano $286 \mathrm{ZnO}$ treatments, $100 \mathrm{mg} \mathrm{L}^{-1}$ was the highest $\mathrm{qP}$ and lowest $\mathrm{qN}$. Neither significant difference in $287 \mathrm{qP}$ and qN was observed for methods of application nor its interaction with Zn treatments.

\subsection{Correlation amongst different photosynthetic and fluorescence parameters}

Amongst different photosynthetic and fluorescence parameters, a significant correlation was evident from our study (Fig. 2). Results showed a highly significant correlation between

291 Chl. a and Chl. b $\left(\mathrm{r}^{2}=0.90\right)$; and Chl. $\mathrm{a}+\mathrm{b}$ and carotenoids $\mathrm{x}+\mathrm{c}\left(\mathrm{r}^{2}=0.82\right)$, indicating a uniform 292 effect of $\mathrm{Zn}$ treatments on these photosynthetic pigments. Significant correlation between SPAD 293 value and extracted $C h l$. a $\left(\mathrm{r}^{2}=0.90\right)$, SPAD value and extracted $C h l . \mathrm{b}\left(\mathrm{r}^{2}=0.94\right)$ and SPAD 
294 value and extracted $C h l . \mathrm{a}+\mathrm{b}\left(\mathrm{r}^{2}=0.93\right)$ indicates validation of our results for the photosynthetic 295 pigments. Significant correlation between Chl. a and photochemical quenching $(\mathrm{qP})\left(\mathrm{r}^{2}=0.46\right)$ and Chl. $\mathrm{b}$ and $\mathrm{qP}\left(\mathrm{r}^{2}=0.57\right)$ indicate a significant effect of increased photosynthetic pigments (a and b) on photosynthetic apparatus. There was a significant correlation between the $\mathrm{qP}$ and quantum yield of photosystem II (Y) $\left(\mathrm{r}^{2}=0.92\right)$ and $\mathrm{qP}$ and EPS II $\left(\mathrm{r}^{2}=72\right)$ and a significant correlation between the $\mathrm{Y}$ and EPS II $\left(\mathrm{r}^{2}=0.60\right)$ indicate improved efficiency of the photosynthetic apparatus through improved photochemical quenching.
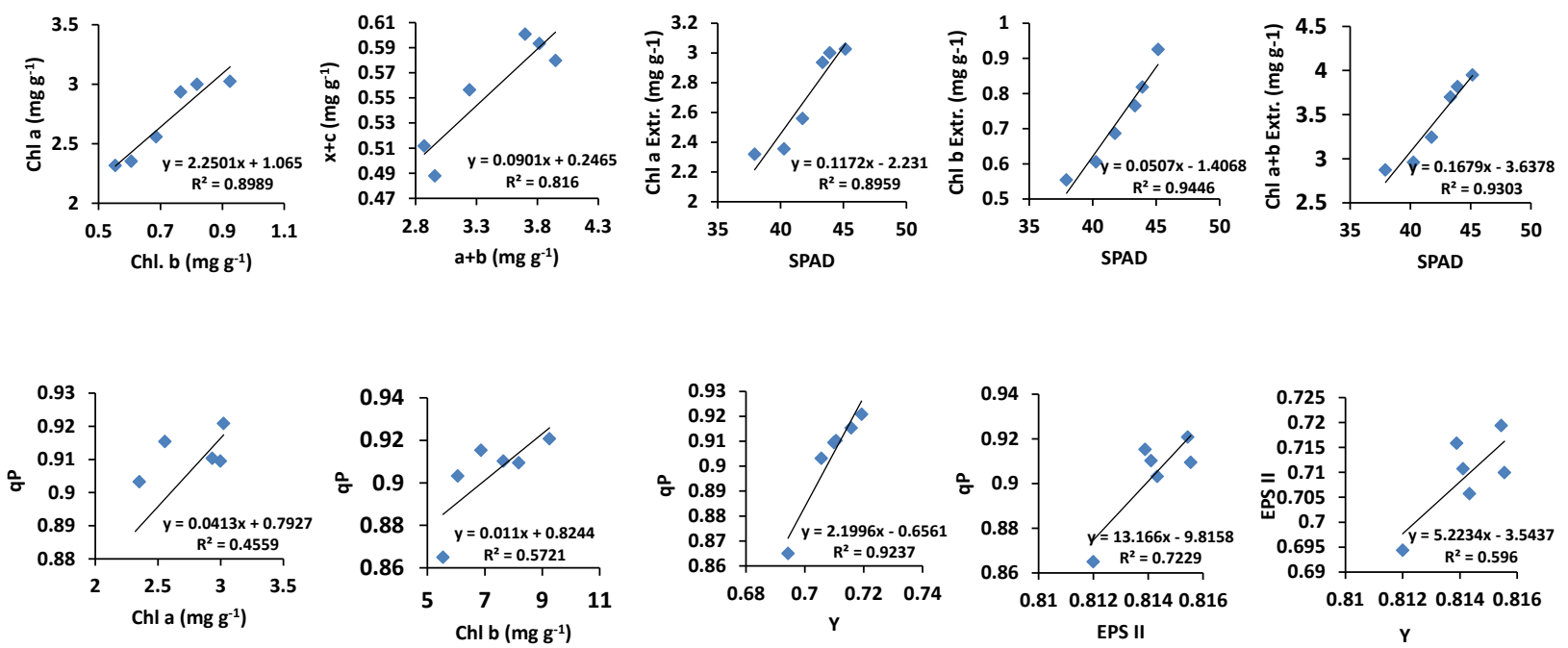

Figure 2 Correlation between Chl. $a$ and Chl. $b$, Chl. $a+b$ and $x+c$, Chl. $a$ and SPAD, Chl. $b$ and SPAD, Chl. $a+b$ and SPAD, Chl. $a$ and photochemical quenching $(q P), C h l . b$ and $q P$, $q P$ and $Y, q P$ and EPS II and EPSII and $Y$.

\subsection{Growth parameters: plant height and biological yield}

All $\mathrm{Zn}$ treatments except nano $\mathrm{ZnO} 50 \mathrm{mg} \mathrm{L}^{-1}$ significantly $(\mathrm{p}<0.01)$ improved the plant

height over $\mathrm{Zn}$ control. Biological yield with nano $\mathrm{ZnO}$ treatments was significantly $(\mathrm{p}<0.01)$

higher over the $\mathrm{ZnSO}_{4}$ applied as soil and $\mathrm{Zn}$ control. Although all nano $\mathrm{ZnO}$ doses were similar 
treatments was non-significant. However, a $2 \%$ improvement $(\mathrm{p}>0.05)$ in plant height was noted

314 with seed coating and foliar application over the soil drench and a $4 \%$ increase $(p>0.05)$ in

315 biological yield with foliar application over the seed coating and soil drench were recorded.
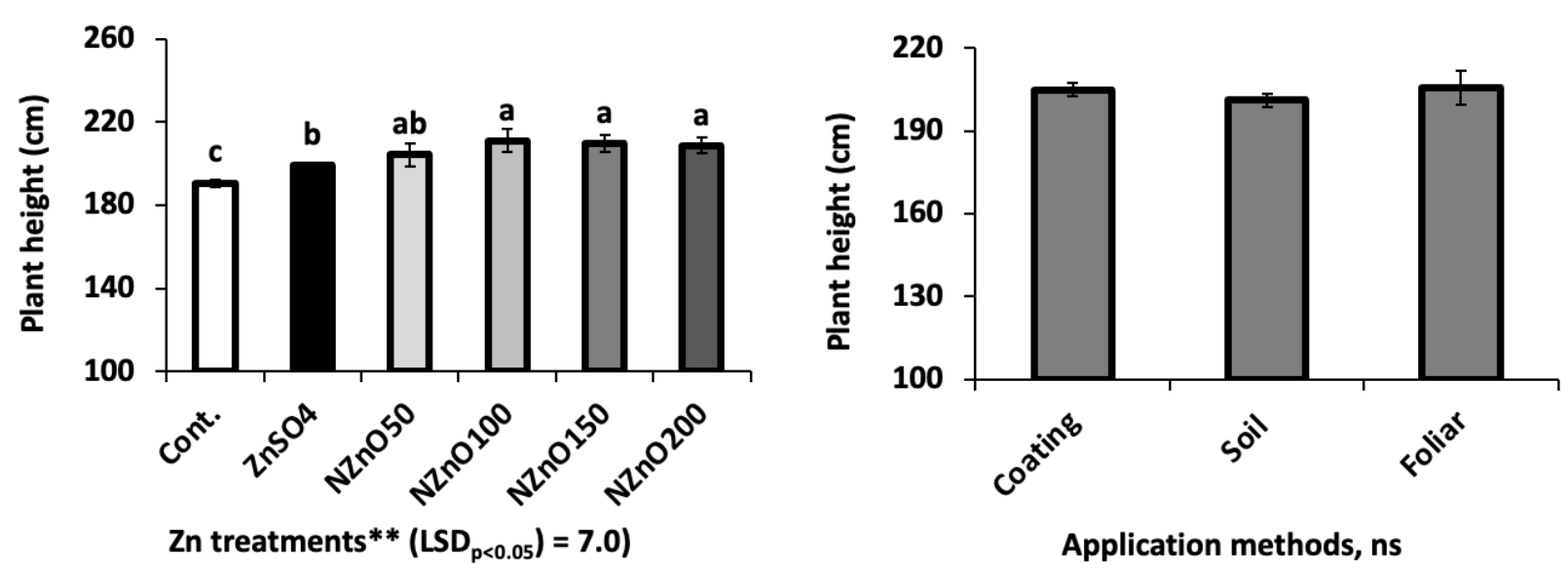

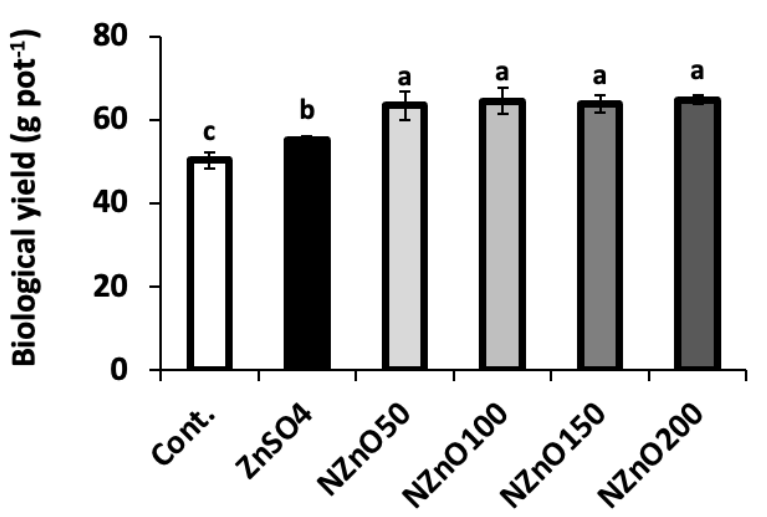

Zn Treatments** $\left(\operatorname{LSD}_{\mathrm{p}<0.05}=3.96\right)$
Application methods, ns

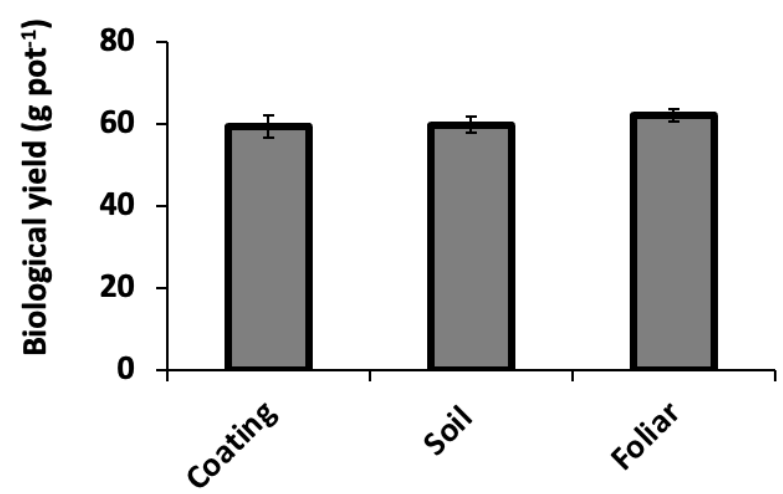

Application methods, ns

Figure 3: Plant height and biological yield among Zn treatments applied through different methods

\section{Discussion}

\subsection{Crop biochemical response to different levels of Nano $\mathrm{ZnO}$}

Zinc is associated with enzymes' activation, structural and catalytic components of proteins.

323 As a co-factor for normal development of pigment biosynthesis (Broadley et al., 2007), its 324 deficiency disrupts the chlorophyll synthesis (Kösesakal \& Ünal, 2009), which can only be 325 restored by optimum $\mathrm{Zn}$ intake (Sadeghzadeh, 2013). Leaf chlorophyll estimation is a less time- 
consuming and cost-effective practice used to predict the crop physiological condition under different environments ( $\mathrm{Yu}$ et al., 2021). Improved chlorophyll with nano $\mathrm{ZnO} 100 \mathrm{mg} \mathrm{L}^{-1}$ compared to other nano $\mathrm{ZnO}$ doses and $\mathrm{ZnSO}_{4}$ suggested improved $\mathrm{Zn}$ availability to crop at this concentration. It could be presumed as an optimum concentration under the current soil conditions. Crop response to applied fertilizer varies according to soil conditions, type, source and amount of fertilizer (Kihara et al., 2016; Islam et al., 2018)) and mode of application (Santos et al., 2020). However, methods of application in our study were non-significant. According to other researchers, nano $\mathrm{ZnO}$ at low doses may act as $\mathrm{Zn}$ fertilizer and provide $\mathrm{Zn}^{+2}$ for plant uptake (Liu et al., 2016). Although $\mathrm{ZnSO}_{4}$ improved the chlorophyll and photosynthetic efficiency compared to $\mathrm{Zn}$ control, low $\mathrm{pH}$ soil and failure to significantly alleviate soil $\mathrm{Zn}$ deficiency limited its absorption for crops Chl. a, b and carotenoids improvement (Subba et al., 2014). The decrease in the effectiveness of nano $\mathrm{ZnO}$ higher and lower than $100 \mathrm{mg} \mathrm{L}^{-1}$ to improve biochemical parameters might be due to $\mathrm{Zn}$ toxicity and deficiency stress, respectively (Subba et al., 2014). Higher than $100 \mathrm{mg} \mathrm{L}^{-1}$ nano $\mathrm{ZnO}$ could be biochemically suppressing the crop that could have resulted in reduced chlorophyll synthesis (Szopiński et al., 2019). Nanoparticle application at higher concentrations negatively affects the terrestrial and aquatic plants and animals (Rajput et al., 2018) and in acid soils, they are more toxic than alkaline soil (Shen et al., 2015).

\subsection{Correlation among SPAD, chlorophyll and carotenoid pigments and its implications}

The $C h l$. a/b ratio is a marker of pigments functionality and adoption of a photosynthetic system to light (Lichtenthaler et al., 1981). Chloroplast, which is responsible for photosynthesis, develops from Proplastids (Charuvi et al., 2012), however, in the absence of light, it may also 
350 develop from other types of plastid, e.g., etioplast. When leaves are exposed to light, pale 351 etioplasts are converted into green chloroplasts by plant cells to acquire photosynthetic 352 competence (Armarego-Marriott et al., 2019). Chl. b is less rapidly accumulated than Chl. a 353 during greening and the $C h l$. a/b ratio turns high, which reverses immediately after greening 354 (Armarego-Marriott et al., 2019), and continues to reduce gradually until it reaches a final ratio 355 of 4.3 reported for fully expanded leaves (Schöttler et al., 2017). Low Chl. a/b ratio means fully 356 developed green leaves, while a high a/b ratio $(4.0$ - 10) implies greening of etiolated leaves 357 (Hartmut et al., 2005). Amongst Zn treatments, significantly $(p<0.01)$ lower $C h l$. a/b ratio for $358100 \mathrm{mg} \mathrm{L}^{-1}$ nano $\mathrm{ZnO}$ (15\% lower than the control) (Table 2) indicated less etiolating fully 359 developed green leaves marking its improved performance for chlorophyll formation and 360 functioning of the photosynthetic apparatus. Higher SPAD values and total chlorophyll content for nano $\mathrm{ZnO}$ over the $\mathrm{ZnSO}_{4}$ (Table 3623 ) indicate significant $(\mathrm{p}<0.05)$ improvement in the crop's physiological conditions. In contrast, 363 the results for nano $\mathrm{ZnO} 100 \mathrm{mg} \mathrm{L}^{-1}$ (Table 3) advocate this dose for further test under different 364 environmental conditions. Increased $\mathrm{Zn}$ availability up to optimum level can improve 365 chlorophyll content, crude proteins and Zn content (Samreen et al., 2017). Thus, a higher SPAD 366 value with $100 \mathrm{mg} \mathrm{L}^{-1}$ nano $\mathrm{ZnO}$ indicates this concentration is more synchronous for higher 367 nutrient accumulation than the other $\mathrm{ZnO}$ doses. Higher SPAD value is tantamount to healthier 368 plants in certain plant species (Minolta, 2009). Reduction in Chlorophyll a, b and total 369 Chlorophyll with higher nano $\mathrm{ZnO}$ doses might be because of stress developed (Noor et al., 370 2018). Besides higher Chl. $\mathrm{a}+\mathrm{b}$ and $\mathrm{x}+\mathrm{c}$, balanced and favorable performance of input is 371 indicated by a relative increase in $a+b / x+c$ ratio. A higher $a+b / x+c$ ratio indicates more greenness 372 of the plant with reduced chances of senescence and vice versa, while it usually ranges from 4.2 
373 (less green) to 5 (more green) under sun-leaves and 5.5 (less green) to 7 (more green) in shade-

374 leaves (Hartmut et al., 2005). In our results, a significantly $(\mathrm{p}<0.01)$ higher $a+b / x+c$ ratio for

375 nano $\mathrm{ZnO} 100 \mathrm{mg} \mathrm{L}^{-1}$ (Table 2) confirms its biochemical advantage over the other doses. Plant

376 growth, chlorophyll contents, crude proteins, and Zn contents were higher when Zn's availability

377 was increased (Samreen et al., 2017). Decreased $C h l . a+b / x+c$ ratio marks the senescence, stress

378 and damage to the photosynthetic system in plants, faster break down of chlorophyll than

379 carotenoids where values lower up to 3.5 exhibits more yellow than green leaves and values

380 below 3 indicate leaves senescence (Hartmut et al., 2005). Also, higher Chl. $\mathrm{a}+\mathrm{b} / \mathrm{x}+\mathrm{c}$ ratio with

$381150 \mathrm{mg} \mathrm{L}^{-1}$ and $200 \mathrm{mg} \mathrm{L}^{-1}$ nano $\mathrm{ZnO}$ applied through soil drench indicate soil matrix effect on

$382 \mathrm{Zn}$ availability and uptake. Zinc deficiency in plants affects photosynthesis due to altered

383 chloroplast pigments (Kösesakal \& Ünal, 2009).

\subsection{Antioxidant enzymatic activity: Proline}

Proline accumulation in plants indicates disturbed physiological conditions because of

386 biotic and abiotic stresses where its presence increases the stress tolerance of plants

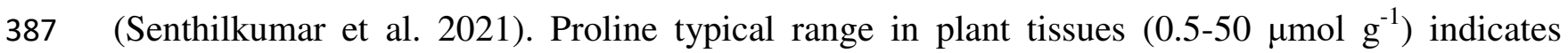

388 increasing stress from lower towards higher value (Carillo \& Gibon, 2011). Proline production is

389 one of the mechanisms for acclimation to stress, higher proline content indicates stress exposure

390 and vice versa (Nazar et al., 2015). Under heavy metals stress, proline acts as a metal chelator

391 and protects enzymes from $\mathrm{Zn}$ and $\mathrm{Cd}$ toxicity by forming complexes with these metals (Sharma

392 et al., 1998). The highest proline concentration in $\mathrm{Zn}$ control (5 times higher than the $\mathrm{ZnSO}_{4}$ )

393 indicates other stress factors present in soil, such as heavy metals like $\mathrm{Al}$ (Table 1), $\mathrm{Pb}, \mathrm{Cu}$ and

394 Cd. Boosted antioxidant activities were reported in plants exposed to Pb (Hussain et al., 2021),

$395 \mathrm{Hg}$ and $\mathrm{Cd}$ (Cruz et al., 2021). Amongst the nano $\mathrm{ZnO}$ doses, the highest proline concentration 
396 was noted for $50 \mathrm{mg} \mathrm{L}^{-1}$ (higher by $162 \%$ than the $150 \mathrm{mg} \mathrm{L}^{-1}$ ) and beyond $150 \mathrm{mg} \mathrm{L}^{-1}$, it 397 increased again. Although the overall content was very low for all treatments than the critical 398 limit $\left(5 \mu \mathrm{mol} \mathrm{g}{ }^{-1}\right)$, further reduction with $\mathrm{Zn}$ application indicates nano $\mathrm{ZnO}$ or $\mathrm{ZnSO}_{4}$ induced 399 relief for crops from already present stress factors in soil. These findings agreed with Hussain et 400 al. (2021), showing reduced proline content with a higher nano $\mathrm{ZnO}$ dose $\left(20 \mathrm{mg} \mathrm{L}^{-1}\right)$. Alia \& 401 Saradhi (1991) reported $\mathrm{Zn}$ as the weakest proline accumulator, as evidenced from our results 402 from $\mathrm{ZnSO}_{4}$ treatments; however, Sun et al. (2020) reported enhanced proline content with 403 enhanced nano ZnO. Proline concentration did not vary with application methods.

404 405

406

407 408 409 410

\subsection{The efficiency of photosystem II}

Reduction $(\mathrm{p}<0.05)$ in the efficiency of photosystem II (EPS II) above $150 \mathrm{mg} \mathrm{L}^{-1}$ and below $100 \mathrm{mg} \mathrm{L}^{-1}$ nano $\mathrm{ZnO}$ (Table 3) confirm the concentration-dependent impact on crop's physiological parameters and tallies well with SPAD (Table 3) and extracted chlorophyll data (Table 2). Significant correlation between $C h l$. a and photochemical quenching $\left(r^{2}=0.45\right)$ and Chl. b and photochemical quenching $\left(\mathrm{r}^{2}=0.57\right)($ Fig. 2) confirmed that increased Chl. a and Chl. b concentration with $100 \mathrm{mg} \mathrm{L}^{-1}$ nano $\mathrm{ZnO}$ resulted in increased efficiency for PS II. The maximum efficiency of photosystems II noted with $100 \mathrm{mg} \mathrm{L}^{-1}$ nano $\mathrm{ZnO}$ is clear proof of better Zn availability within these limits which may have increased the number of reaction centers in photosystems.

Reduced efficiency of PSII suggests toxic effects of supplemental Zn from higher nano $\mathrm{ZnO}$ concentrations $\left(200 \mathrm{mg} \mathrm{L}^{-1}\right)$ over and above the required limits, which is deemed to have reduced the flow of electrons from PSII to PSI (Santos et al., 2021). More importantly, the lower $\left(50 \mathrm{mg} \mathrm{L}^{-1}\right)$ and moderate $\left(100\right.$ and $\left.150 \mathrm{mg} \mathrm{L}^{-1}\right)$ concentration treatments either improved or maintained the physiological functions of the crop suggesting their absorption and utilization by 
419 plants better than $\mathrm{ZnSO}_{4}$ (Prasad et al., 2012). The findings emphasized for an optimum $\mathrm{ZnO}$

420 dose application to plants that could supplement $\mathrm{Zn}$ requirements for growth and development

421 and its structural and enzymatic activities (Subba et al., 2014; Singh et al., 2018).

422

423

424

425

426

427

428

429

430

431

432

433

434

435

436

437

438

439

440

441

\subsection{Growth parameters: Plant height and biological yield}

Significantly $(\mathrm{p}<0.01)$ improved plant height, and biological yield over the $\mathrm{Zn}$ control through Zn treatments of the crop is supported by increased chlorophyll content (Table 2) and photosynthetic efficiency (Table 3) which might have higher photosynthetic assimilates than $\mathrm{Zn}$ deficient plants. The same holds good for further significant improvement in plant height and biological yield with nano $\mathrm{ZnO}$ over the recommended $\mathrm{ZnSO}_{4}$ dose. This could be due to much higher $\mathrm{Zn}$ uptake from nano $\mathrm{ZnO}$ than the $\mathrm{Zn}^{2+}$ treated plants (Zhang et al., 2015). However, the nano $\mathrm{ZnO} 100 \mathrm{mg} \mathrm{L}^{-1}$ concentration seems to have maximum $\mathrm{Zn}$ availability with abiotic stress mitigation on the plant, as is evident from significantly lower proline content (Table 3) and therefore, secured the maximum growth. Sun et al. (2020) revealed that $100 \mathrm{mg} \mathrm{L}^{-1}$ nano $\mathrm{ZnO}$ improved plant resistance to stress conditions and supported higher plant growth compared to the control. Increased photochemical quenching at $100 \mathrm{mg} \mathrm{L}^{-1}$ nano $\mathrm{ZnO}$ level could have enhanced the rate of photophosphorylation to meet ATP requirements for other physiological activities of the plants which could have increased the ultimate crop growth up to an optimum concentration (Singh et al., 2018; Del Buono et al., 2021). Furthermore, this study confirms the fundamental role of a certain amount of $\mathrm{Zn}$ as a nutrient for optimum growth and produce (Sadeghzadeh, 2013), cell elongation, membrane structure, stability and environmental stress tolerance and protection (Marreiro et al., 2017; Tufail et al., 2017; Bafaro et al., 2017; Tufail et al., 2017). 
The enhancement in chlorophyll pigments, SPAD value, photochemical quenching and 444 efficiency of photosystems, growth and yield elucidate that nanoforms of zinc oxide play a 445 positive role in the biochemical health and functioning of maize up to a particular concentration. 446 Crop's positive response towards nano- $\mathrm{ZnO}$ was more pronounced at $100 \mathrm{mg} \mathrm{L}^{-1}$ than its lower 447 and higher doses and the conventional $\mathrm{ZnSO}_{4}$ fertilizer recommended dose. Either seed coating, 448 soil drench, or foliar spray can be used for nano $\mathrm{ZnO}$ application. Notwithstanding, foliar 449 application had a non-significant edge over the other methods. Thus, nano $\mathrm{ZnO}$ up to $100 \mathrm{mg} \mathrm{L}^{-1}$ 450 can be recommended to improve crop's biochemical health and functioning, irrespective of the 451 application modes, in Zn deficient acidic Spodosol soil for improving maize crop growth through 452 Zn bio-fortification.

\section{Acknowledgments}

The authors acknowledge the Higher Education Commission (HEC) of Pakistan for 455 supporting Dr. Ahmad's visit to the University of Florida, United States as Post Doc Research 456 Scholar and the University of Florida for conducting this research. The authors also thank Mr. 457 Brian Cain for assistance with sample analysis.

\section{Declaration of competing interest:}

459 No financial or personal interests appear to exist amongst the authors that might influence the $460 \quad$ work reported in this paper.

\section{Funding statement:}

This research did not receive any specific grant from funding agencies in the public, commercial, or not-for-profit sectors. 


\section{References}

Adhikari, T., Kundu, S., Biswas, A. K., Tarafdar, J. C., \& Subba Rao, A. (2015). Characterization of Zinc Oxide Nano Particles and Their Effect on Growth of Maize (Zea mays L.) Plant. Journal of Plant Nutrition, 38(10), 1505-1515. https://doi.org/10.1080/01904167.2014.992536

Ahmed, N., Habib, U., Younis, U., Irshad, I., Danish, S., Rahi, A. A., \& Munir, T. M. (2020). Growth, chlorophyll content and productivity responses of maize to magnesium sulphate application in calcareous soil. Open Agriculture, 5(1), 792-800. https://doi.org/10.1515/opag-2020-0023

Ahmad, N. (2004). Fertilizer use by crop in Pakistan. Retrieved from: https://www.fao.org/3/y5460e/y5460e00.htm\#contents

Alia, \& Saradhi, P. P. (1991). Proline Accumulation Under Heavy Metal Stress. Journal of Plant Physiology, 138(5), 554-558. https://doi.org/10.1016/S0176-1617(11)80240-3

Arafat, Y., Shafi, M., Khan, M. A., Adnan, M., Basir, A., Arshad, M., ... \& Shah, J. A. (2016). Yield response of wheat cultivars to zinc application rates and methods. Pure and Applied Biology, 5(4), 1.

Armarego-Marriott, T., Kowalewska, Ł., Burgos, A., Fischer, A., Thiele, W., Erban, A., Strand, D., Kahlau, S., Hertle, A., Kopka, J., Walther, D., Reich, Z., Schöttler, M. A., \& Bock, R. (2019). Highly resolved systems biology to dissect the etioplast-to-chloroplast transition in tobacco leaves. Plant Physiology, 180(1), 654-681. https://doi.org/10.1104/pp.18.01432

Bafaro, E., Liu, Y., Xu, Y., \& Dempski, R. E. (2017). The emerging role of zinc transporters in cellular homeostasis and cancer. Signal Transduction and Targeted Therapy, 2(February), 1-12. https://doi.org/10.1038/sigtrans.2017.29

BATES, L. S. (1973). SHORT COMMUNICATION Rapid determination of free proline for $w$ a $t$ e r - s t r e s s studies. 207, 205-207.

Bhatt, R., Hossain, A., \& Sharma, P. (2020). Zinc biofortification as an innovative technology to alleviate the zinc deficiency in human health: A review. Open Agriculture, 5(1), 176-186. https://doi.org/10.1515/opag-2020-0018

Broadley, M. R., White, P. J., Hammond, J. P., Zelko, I., Lux, A. (2007). Zinc in plants. New Phytol., 173, 677-702.

Cakmak, I., \& Kutman, U. B. (2018). Agronomic biofortification of cereals with zinc: a review. European Journal of Soil Science, 69(1), 172-180. https://doi.org/10.1111/ejss.12437

Carillo, P., \& Gibon, Y. (2011). PROTOCOL: Extraction and determination of Proline. -. https://www.researchgate.net/publication/211353600

Charuvi, D., Kiss, V., Nevo, R., Shimoni, E., Adam, Z., \& Reich, Z. (2012). Gain and loss of photosynthetic membranes during plastid differentiation in the shoot apex of arabidopsis. Plant Cell, 24(3), 1143-1157. https://doi.org/10.1105/tpc.111.094458

Chen, W., Yang, X., He, Z., Feng, Y., \& Hu, F. (2008). Differential changes in photosynthetic 
capacity, $77 \mathrm{~K}$ chlorophyll fluorescence and chloroplast ultrastructure between Zn-efficient and Zn-inefficient rice genotypes (Oryza sativa) under low zinc stress. Physiologia Plantarum, 132(1), 89-101. https://doi.org/10.1111/j.1399-3054.2007.00992.x

Cruz, Y., Villar, S., Gutiérrez, K., Montoya-Ruiz, C., Gallego, J. L., Delgado, M. del P., \& Saldarriaga, J. F. (2021). Gene expression and morphological responses of Lolium perenne L. exposed to cadmium (Cd2+) and mercury (Hg2+). Scientific Reports, 11(1), 1-11. https://doi.org/10.1038/s41598-021-90826-y

Del Buono, D., Di Michele, A., Costantino, F., Trevisan, M., \& Lucini, L. (2021). Biogenic zno nanoparticles synthesized using a novel plant extract: Application to enhance physiological and biochemical traits in maize. Nanomaterials, 11(5). https://doi.org/10.3390/nano11051270

Elemike, E. E., Uzoh, I. M., Onwudiwe, D. C., \& Babalola, O. O. (2019). The role of nanotechnology in the fortification of plant nutrients and improvement of crop production. Applied Sciences (Switzerland), 9(3), 1-32. https://doi.org/10.3390/app9030499

García-Gómez, C., García-Gutiérrez, S., Obrador, A., \& Fernández, M. D. (2020). Study of Zn availability, uptake, and effects on earthworms of zinc oxide nanoparticle versus bulk applied to two agricultural soils: Acidic and calcareous. Chemosphere, 239. https://doi.org/10.1016/j.chemosphere.2019.124814

Hayyawi, N. J. H., Al-Issawi, M. H., Alrajhi, A. A., Al-Shmgani, H., \& Rihan, H. (2020). Molybdenum Induces Growth, Yield, and Defence System Mechanisms of the Mung Bean (Vigna radiata L.) under Water Stress Conditions. International Journal of Agronomy, 2020. https://doi.org/10.1155/2020/8887329

Hossain, A., Mottaleb, K. A., Farhad, M., \& Deb Barma, N. C. (2019). Mitigating the twin problems of malnutrition and wheat blast by one wheat variety, "BARI Gom 33", in Bangladesh. Acta Agrobotanica, 72(2). https://doi.org/10.5586/aa.1775

Hussain, F., Hadi, F., \& Rongliang, Q. (2021). Effects of zinc oxide nanoparticles on antioxidants, chlorophyll contents, and proline in Persicaria hydropiper L. and its potential for Pb phytoremediation. Environmental Science and Pollution Research, 28(26), 3469734713. https://doi.org/10.1007/s11356-021-13132-0

Islam, S., Hamid, F. S., Shah, B. H., Zaman, Q., Khan, N., Ahmad, F., \& Aftab, S. (2018). Response of Organic \& Inorganic Fertilizers to the Growth, Yield and Soil Nutrient Status in Tomato (Lycopersion esculentum). Open Academic Journal of Advanced Science and Technology, 2(1), 1-4. https://doi.org/10.33094/5.2017.2018.21.1.4

Janet C King, Kenneth H Brown, Rosalind S Gibson, Nancy F Krebs, N. M. L., \& Jonathan H Siekmann, and D. J. R. (2016). Biomarkers of Nutrition for Development (BOND)-Zinc review. Journal of Nutrition, 146(4), 858S-885S. https://doi.org/doi:10.3945/jn.115.220079.

Kihara, J., Nziguheba, G., Zingore, S., Coulibaly, A., Esilaba, A., Kabambe, V., Njoroge, S., Palm, C., \& Huising, J. (2016). Understanding variability in crop response to fertilizer and amendments in sub-Saharan Africa. Agriculture, Ecosystems and Environment, 229, 1-12. https://doi.org/10.1016/j.agee.2016.05.012 
Kösesakal, T., \& Ünal, M. (2009). Role of Zinc Deficiency in Photosynthetic Pigments and Peroxidase Activity of Tomato Seedlings. IUFS Journal of Biology, 68(2), 113-120. https://doi.org/10.18478/iufsjb.62201

Lichtenthaler, H. K., Buschmann, C., Döll, M., Fietz, H. J., Bach, T., Kozel, U., Meier, D., \& Rahmsdorf, U. (1981). Photosynthetic activity, chloroplast ultrastructure, and leaf characteristics of high-light and low-light plants and of sun and shade leaves. Photosynthesis Research, 2(2), 115-141. https://doi.org/10.1007/BF00028752

Lichtenthaler, Hartmut K., \& Buschmann, C. (2001). Extraction of Phtosynthetic Tissues:Chlorophylls and Carotenoids. Current Protocols in Food Analytical Chemistry, 1(1), F4.2.1-F4.2.6. https://doi.org/10.1002/0471142913.faf0402s01

Lichtenthaler, Hartmut K., \& Buschmann, C. (2005). Chlorophylls and Carotenoids: Measurement And Characterization by UV-VIS Spectroscopy. Handbook of Food Analytical Chemistry, 2-2, 171-178. https://doi.org/10.1002/0471709085.ch21

Liu, H., Gan, W., Rengel, Z., \& Zhao, P. (2016). Effects of zinc fertilizer rate and application method on photosynthetic characteristics and grain yield of summer maize. Journal of Soil Science and Plant Nutrition, 16(2), 550-562. https://doi.org/10.4067/S071895162016005000045

Marreiro, D. do N., Cruz, K. J. C., Morais, J. B. S., Beserra, J. B., Severo, J. S., \& Soares de Oliveira, A. R. (2017). Zinc and oxidative stress: Current mechanisms. Antioxidants, 6(2). https://doi.org/10.3390/antiox6020024

Mehlich, A. (1984). Access details: Access Details: [ subscription number 731847469 ] Communications in Soil Science and Plant Analysis Mehlich 3 soil test extractant: A modification of Mehlich 2 extractant. 731847469, 37-41.

Minolta, K. (2009). A lightweight handheld meter for leaves without causing damage to plants. https://www.konicaminolta.com/instruments/download/catalog/color/pdf/spad502plus_catal og_eng.pdf

Moghaddasi, S., Fotovat, A., Khoshgoftarmanesh, A. H., Karimzadeh, F., Khazaei, H. R., \& Khorassani, R. (2017). Bioavailability of coated and uncoated $\mathrm{ZnO}$ nanoparticles to cucumber in soil with or without organic matter. Ecotoxicology and Environmental Safety, 144(January), 543-551. https://doi.org/10.1016/j.ecoenv.2017.06.074

Nadeem, F., \& Farooq, M. (2019). Application of Micronutrients in Rice-Wheat Cropping System of South Asia. Rice Science, 26(6), 356-371. https://doi.org/10.1016/j.rsci.2019.02.002

Nazar, R., Umar, S., Khan, N. A., \& Sareer, O. (2015). Salicylic acid supplementation improves photosynthesis and growth in mustard through changes in proline accumulation and ethylene formation under drought stress. South African Journal of Botany, 98, 84-94. https://doi.org/10.1016/j.sajb.2015.02.005

Noor, S., Ali, S., Hafeez-ur-Rahman, Farhatullah, \& Ali, G. M. (2018). Comparative study of transgenic (DREB1A) and non-transgenic wheat lines on relative water content, sugar, proline and chlorophyll under drought and salt stresses. Sarhad Journal of Agriculture, 
Oxborough, K., \& Baker, N. R. (1997). Resolving chlorophyll a fluorescence images of photosynthetic efficiency into photochemical and non-photochemical components Calculation of $\mathrm{qP}$ and Fv'/Fm' without measuring Fo'. Photosynthesis Research, 54(2), 135-142. https://doi.org/10.1023/A:1005936823310

Prasad, T. N. V. K. V., Sudhakar, P., Sreenivasulu, Y., Latha, P., Munaswamy, V., Raja Reddy, K., Sreeprasad, T. S., Sajanlal, P. R., \& Pradeep, T. (2012). Effect of nanoscale zinc oxide particles on the germination, growth and yield of peanut. Journal of Plant Nutrition, 35(6), 905-927. https://doi.org/10.1080/01904167.2012.663443

Rajput, V. D., Minkina, T. M., Behal, A., Sushkova, S. N., Mandzhieva, S., Singh, R., Gorovtsov, A., Tsitsuashvili, V. S., Purvis, W. O., Ghazaryan, K. A., \& Movsesyan, H. S. (2018). Effects of zinc-oxide nanoparticles on soil, plants, animals and soil organisms: A review. Environmental Nanotechnology, Monitoring and Management, 9(May), 76-84. https://doi.org/10.1016/j.enmm.2017.12.006

Recena, R., García-López, A. M., \& Delgado, A. (2021). Zinc Uptake by Plants as Affected by Fertilization with Zn Sulfate, Phosphorus Availability, and Soil Properties. Agronomy, 11(2), 390. https://doi.org/10.3390/agronomy11020390

Reddy Pullagurala, V. L., Adisa, I. O., Rawat, S., Kalagara, S., Hernandez-Viezcas, J. A., Peralta-Videa, J. R., \& Gardea-Torresdey, J. L. (2018). ZnO nanoparticles increase photosynthetic pigments and decrease lipid peroxidation in soil grown cilantro (Coriandrum sativum). Plant Physiology and Biochemistry, 132(August), 120-127. https://doi.org/10.1016/j.plaphy.2018.08.037

Rizwan, M., Ali, S., Qayyum, M. F., Ok, Y. S., Adrees, M., Ibrahim, M., Zia-ur-Rehman, M., Farid, M., \& Abbas, F. (2017). Effect of metal and metal oxide nanoparticles on growth and physiology of globally important food crops: A critical review. Journal of Hazardous Materials, 322, 2-16. https://doi.org/10.1016/j.jhazmat.2016.05.061

Sabir, S., Arshad, M., \& Chaudhari, S. K. (2014). Zinc oxide nanoparticles for revolutionizing agriculture: Synthesis and applications. Scientific World Journal, 2014. https://doi.org/10.1155/2014/925494

Sadeghzadeh, B. (2013). A review of zinc nutrition and plant breeding. Journal of Soil Science and Plant Nutrition, 13(4), 907-927. https://doi.org/10.4067/S0718-95162013005000072

Salam, A., Khan, A. R., Liu, L., Yang, S., Azhar, W., Ulhassan, Z., Zeeshan, M., Wu, J., Fan, X., \& Gan, Y. (2022). Seed priming with zinc oxide nanoparticles downplayed ultrastructural damage and improved photosynthetic apparatus in maize under cobalt stress. Journal of Hazardous Materials, 423(PA), 127021. https://doi.org/10.1016/j.jhazmat.2021.127021

Samreen, T., Humaira, Shah, H. U., Ullah, S., \& Javid, M. (2017). Zinc effect on growth rate, chlorophyll, protein and mineral contents of hydroponically grown mungbeans plant (Vigna radiata). Arabian Journal of Chemistry, 10, S1802-S1807. https://doi.org/10.1016/j.arabjc.2013.07.005

Santos, A. J. M., Backes, C., Rodrigues, L. M., Teodoro, A. G., de Godoy, L. J. G., Tomazello, 
D. A., Campos, L. F. C., Ribon, A. A., Lopes, T. A., \& Boas, R. L. V. (2020). Chemical characteristics of soil after application of tannery sludge as fertilizer in the sugarcane plant crop. Australian Journal of Crop Science, 14(4), 641-648. https://doi.org/10.21475/ajcs.20.14.04.p2234

Santos, E. F., Pongrac, P., Reis, A. R., Rabêlo, F. H. S., Azevedo, R. A., White, P. J., \& Lavres, J. (2021). Unravelling homeostasis effects of phosphorus and zinc nutrition by leaf photochemistry and metabolic adjustment in cotton plants. Scientific Reports, 11(1), 1-14. https://doi.org/10.1038/s41598-021-93396-1

Schöttler, M. A., Thiele, W., Belkius, K., Bergner, S. V., Flügel, C., Wittenberg, G., Agrawal, S., Stegemann, S., Ruf, S., \& Bock, R. (2017). The plastid-encoded PsaI subunit stabilizes photosystem i during leaf senescence in tobacco. Journal of Experimental Botany, 68(5), 1137-1155. https://doi.org/10.1093/jxb/erx009

Senthilkumar, M., Amaresan N., S. A. (2021). Plant-Microbe Interactions:Laboratory techniques.

Sharma, S. S., Schat, H., \& Vooijs, R. (1998). In vitro alleviation of heavy metal-induced enzyme inhibition by proline. Phytochemistry, 49(6), 1531-1535. https://doi.org/10.1016/S0031-9422(98)00282-9

Shen, Z., Chen, Z., Hou, Z., Li, T., \& Lu, X. (2015). Ecotoxicological effect of zinc oxide nanoparticles on soil microorganisms. Frontiers of Environmental Science and Engineering, 9(5), 912-918. https://doi.org/10.1007/s11783-015-0789-7

Singh, A., Prasad, S. M., \& Singh, S. (2018). Impact of nano ZnO on metabolic attributes and fluorescence kinetics of rice seedlings. Environmental Nanotechnology, Monitoring and Management, 9(July 2017), 42-49. https://doi.org/10.1016/j.enmm.2017.11.006

Subba, P., Mukhopadhyay, M., Mahato, S. K., Bhutia, K. D., Mondal, T. K., \& Ghosh, S. K. (2014). Zinc stress induces physiological, ultra-structural and biochemical changes in mandarin orange (Citrus reticulata Blanco) seedlings. Physiology and Molecular Biology of Plants, 20(4), 461-473. https://doi.org/10.1007/s12298-014-0254-2

Sun, L., Song, F., Guo, J., Zhu, X., Liu, S., Liu, F., \& Li, X. (2020). Nano-ZnO-induced drought tolerance is associated with melatonin synthesis and metabolism in maize. International Journal of Molecular Sciences, 21(3), 1-18. https://doi.org/10.3390/ijms21030782

Szopiński, M., Sitko, K., Gieroń, Ż., Rusinowski, S., Corso, M., Hermans, C., Verbruggen, N., \& Małkowski, E. (2019). Toxic effects of cd and zn on the photosynthetic apparatus of the Arabidopsis halleri and Arabidopsis arenosa pseudo-metallophytes. Frontiers in Plant Science, 10(June), 1-13. https://doi.org/10.3389/fpls.2019.00748

Taheri, M., Qarache, H. A., Qarache, A. A., \& Yoosefi, M. (2015). The Effects of Zinc-Oxide Nanoparticles on Growth Parameters of Corn (SC704). STEM Fellowship Journal, 1(2), 1720. https://doi.org/10.17975/sfj-2015-011

Tufail, A., Li, H., Naeem, A., \& Li, T. X. (2017). Leaf cell membrane stability-based mechanisms of zinc nutrition in mitigating salinity stress in rice. In Plant Biology (Vol. 20, Issue 2). https://doi.org/doi:10.1111/plb.12665 
662 Wang, H., Liu, R. L., \& Jin, J. Y. (2009). Effects of zinc and soil moisture on photosynthetic rate 663 and chlorophyll fluorescence parameters of maize. Biologia Plantarum, 53(1), 191-194. https://doi.org/10.1007/s10535-009-0033-z

665 Yu, S., Zhang, N., Kaiser, E., Li, G., An, D., Sun, Q., Chen, W., Liu, W., \& Luo, W. (2021). 666 Integrating chlorophyll fluorescence parameters into a crop model improves growth 667 668 prediction under severe drought. Agricultural and Forest Meteorology, 303(October 2020), 108367. https://doi.org/10.1016/j.agrformet.2021.108367

670

671

672

Zhang, R., Zhang, H., Tu, C., Hu, X., Li, L., Luo, Y., \& Christie, P. (2015). Phytotoxicity of $\mathrm{ZnO}$ nanoparticles and the released $\mathrm{Zn}$ (II) ion to corn (Zea mays L.) and cucumber (Cucumis sativus L.) during germination. Environmental Science and Pollution Research, 673 